\title{
Interesting association of neurofibroma with diffuse cystic lung disease (NF-DLD)
}

Sharath P Madhyastha, Vinaya Gopalaswamy, Charan Thej Reddy, Raviraja V Acharya

Internal Medicine, Kasturba Medical College, Manipal, Manipal, Karnataka, India

\section{Correspondence to} Dr Sharath P Madhyastha, dr.sharathymc@gmail.com

Accepted 11 January 2017
CrossMark

To cite: Madhyastha SP, Gopalaswamy V, Reddy CT, et al. BMJ Case Rep Published online: [please include Day Month Year] doi:10.1136/bcr-2016217774

\section{DESCRIPTION}

A man aged 46 years presented with gradually progressive weakness of bilateral lower limbs and reduced sensation below the level of nipple for the past 2 months. There was no history of upper limb weakness and his bowel and bladder movements were normal. On enquiry, he also has a 2-year

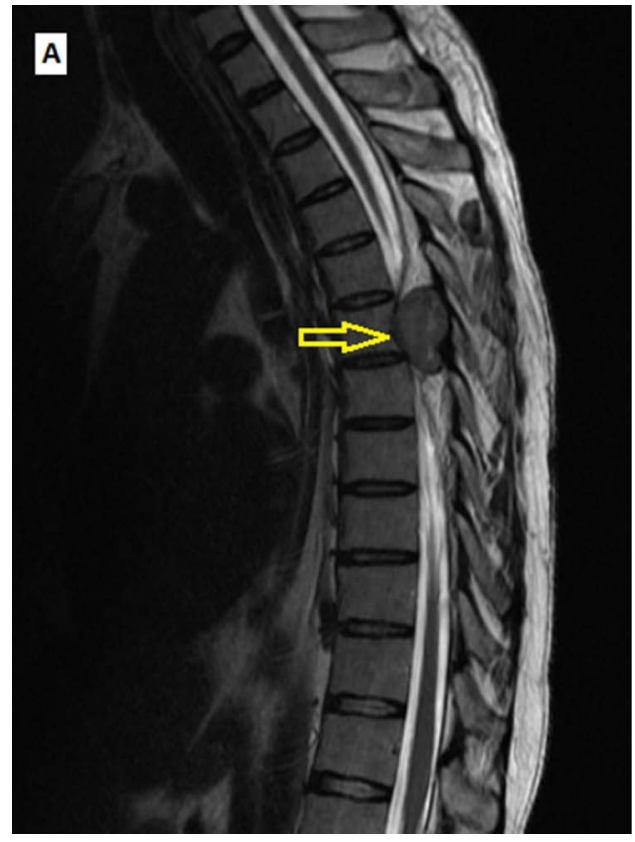

history of dry cough, wheeze and exertional dyspnoea. He is a non-smoker with no other significant medical history. On examination, power of bilateral lower limbs was $0 / 5$, and knee and ankle reflexes were brisk with extensor plantar response. The patient had decreased sensation below the level of D5 vertebra. He had bilateral occasional

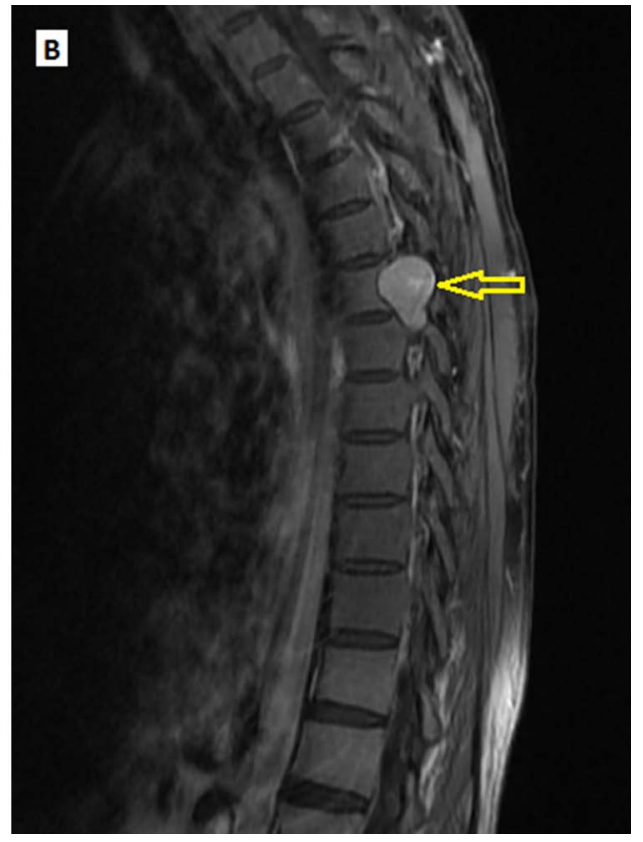

Figure 1 MRI of the spinal cord, sagittal view, (A) T2-weighted, (B) T1-weighted, showing benign intraspinal extradural dumb-bell-shaped neurogenic tumour measuring $3.8 \times 2.0 \times 3.0 \mathrm{~cm}$ at the $\mathrm{D6}-7$ level (arrow) causing significant spinal cord compression.

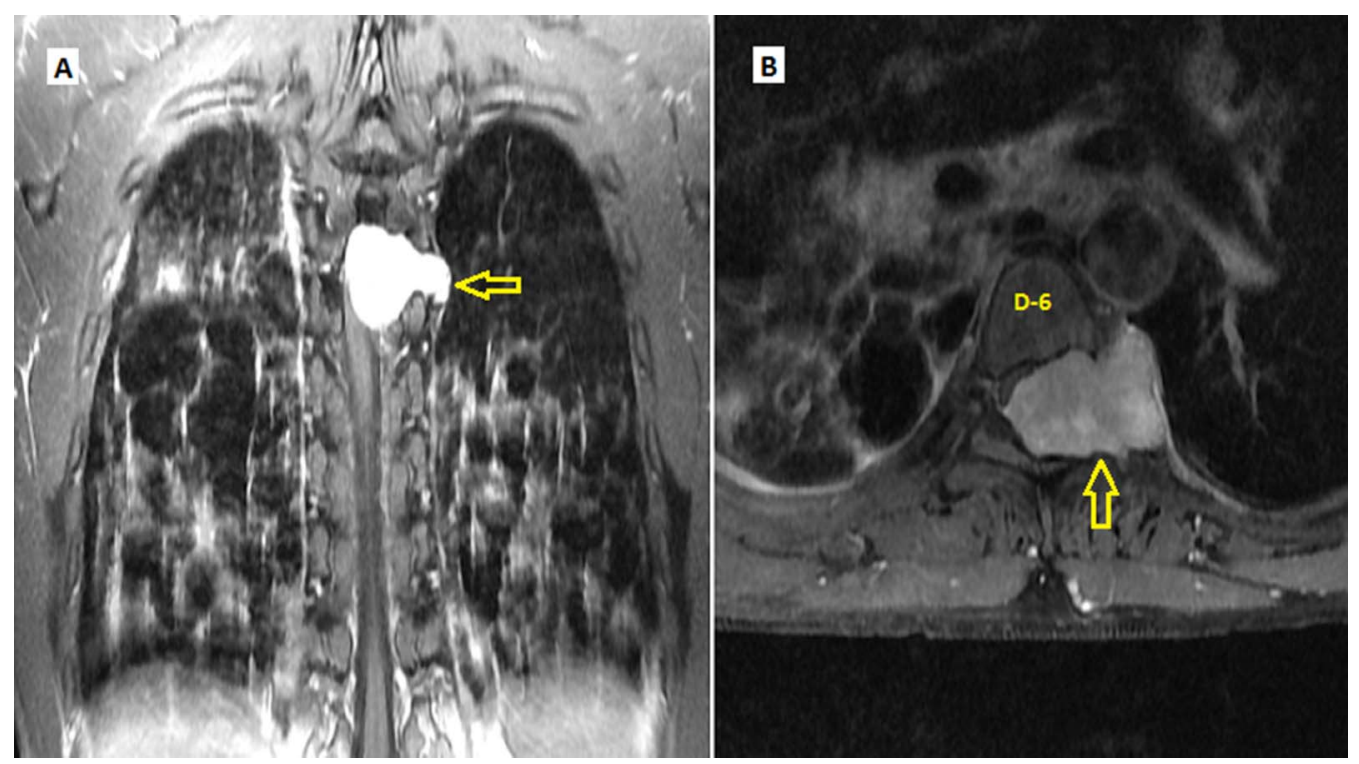

Figure 2 Coronal (A) and axial (B) images of MRI spinal cord showing neurofibroma (dumb-bell-shaped) at the D6 level (arrow) causing significant compression and rightward displacement of the spinal cord. 


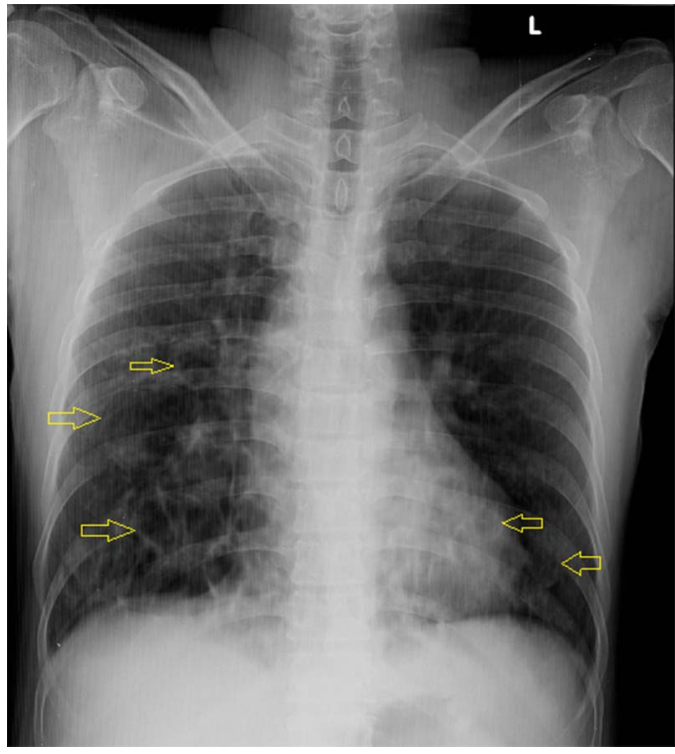

Figure 3 Chest radiograph showing cystic bronchiectatic changes (arrows) in both lower zones. rhonchi on chest auscultation. MRI of the spinal cord revealed benign intraspinal extradural dumb-bell-shaped lesion, measuring $3.8 \times 2.0 \times 3.0 \mathrm{~cm}$, isointense on $\mathrm{T} 2 \mathrm{WI}$, hyperintense on T1WI, STIR noted at the D6-7 level causing significant spinal cord compression suggestive of neurogenic tumour (Neurofibroma/Schwannoma) (figures 1 and 2). Chest X-ray showed features of cystic bronchiectatic changes in both lower zones (figure 3) which was confirmed by CECT chest (figure 4). Cystic bronchiectatic changes were present in both the lungs (bilateral lower lobes, apical and posterior segments of the right upper lobe, posterior segment of the left upper lobe). The patient underwent D6 laminectomy, excision of the tumour with D5 and D7 transpedicular stabilisation (figure 5). Histopathology of the excised tumour showed interlacing bundles of spindle-shaped cells, having elongated nuclei and eosinophilic cytoplasmic process, fibroblasts and proliferating capillaries, consistent with the diagnosis of neurofibroma (figure 6). Lower limb weakness was gradually improved with the power of $3 / 5$ at the time of discharge.

Association of neurofibromatosis with diffuse lung disease (NF-DLD) was first described by Davies way back in $1963 .{ }^{1}$ But the exact prevalence and reason for its association is still
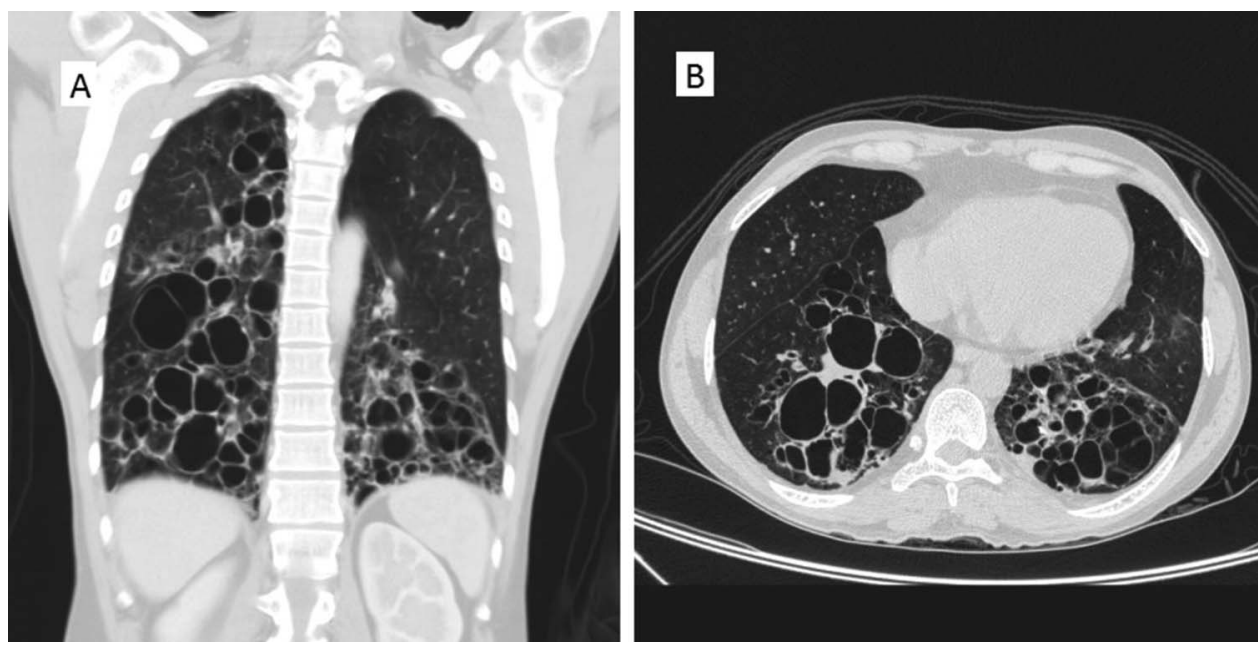

Figure 4 Coronal (A) and axial (B) images of CT chest showing cystic bronchiectatic changes in bilateral lower lobes, apical and posterior segments of the right upper lobe and posterior segment of the left upper lobe.

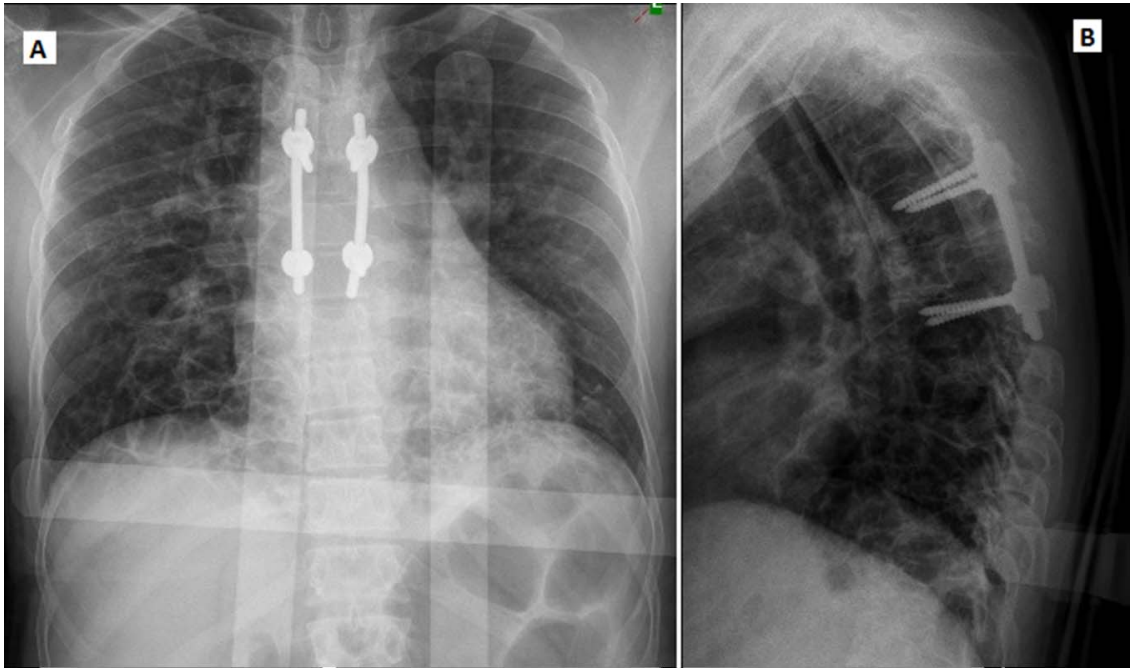

Figure 5 Postoperative, frontal (A) and lateral (B) radiograph of the chest with spinal fixative device is seen at the D4-7 level (transpedicular stabilisation). 

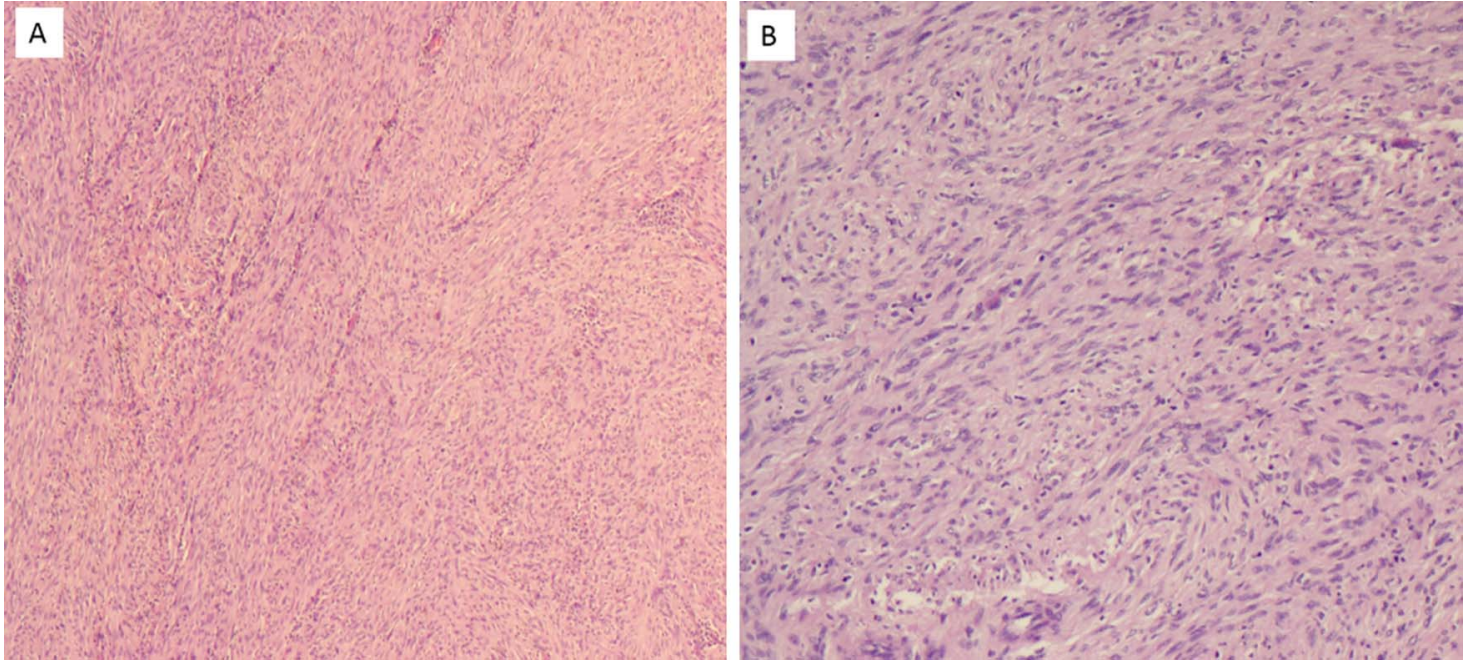

Figure 6 Histopathology of the excised tumour at low power $(A)$ and high power (B) showing interlacing bundles of spindle-shaped cells, having elongated wavy nuclei and eosinophilic cytoplasmic process, fibroblasts, proliferating capillaries.

unclear. According to one largest retrospective case series and literature review, one-fourth of the cases had cystic lung disease on HRCT. Other lung lesions encountered were ground-glass opacities, bibasilar reticular opacities, bullae and emphysema. ${ }^{2}$

However, almost all previously described cases had upper lobe cystic and bullous disease and basilar fibrosis unlike our patient who had predominantly lower lobe involvement. The close differential diagnosis for this could be cystic fibrosis and recurrent pneumonias. In both these conditions, there will be symptoms suggestive of recurrent respiratory tract infections and in cystic fibrosis other specific phenotypic features. Our

\section{Learning points}

- Treatable causes should be kept in mind in every case of paraplegia.

- One should be aware of this association of neurofibromatosis with diffuse lung disease. patient did not had any of such symptoms and hence we believe this is a pure association with NF-DLD.

Acknowledgements The authors would like to express their deepest appreciation to Dr Kanthilatha Pai (Professor, Department of Pathology) who provided and commented on the histopathology pictures, Dr Lakshmikanth H K (Assistant Professor, Department of Radiodiagnosis) for reporting MRI and CT images, Dr Akhila D, Medical officer, Department of community Medicine, for language correction and all the colleagues who were involved in the care of our patient.

Contributors SPM, VG and CTR drafted the manuscript. RVA involved in patient management. SPM performed the literature search, revision, correction and final editing of the manuscript. All the authors reviewed and approved for final submission.

Competing interests None declared.

Patient consent Obtained.

Provenance and peer review Not commissioned; externally peer reviewed.

\section{REFERENCES}

1 Davies PBD. Diffuse pulmonary involvement in von Recklinhausen's disease: a new syndrome. Thorax 1963:18:198.

2 Zamora A, Collard $\mathrm{H}$, Wolters $\mathrm{P}$, et al. Neurofibromatosis-associated lung disease: a case series and literature review. Eur Respir J 2006:29:210-14.

Copyright 2017 BMJ Publishing Group. All rights reserved. For permission to reuse any of this content visit http://group.bmi.com/group/rights-licensing/permissions.

BMJ Case Report Fellows may re-use this article for personal use and teaching without any further permission.

Become a Fellow of BMJ Case Reports today and you can:

- Submit as many cases as you like

- Enjoy fast sympathetic peer review and rapid publication of accepted articles

- Access all the published articles

- Re-use any of the published material for personal use and teaching without further permission

For information on Institutional Fellowships contact consortiasales@bmjgroup.com

Visit casereports.bmj.com for more articles like this and to become a Fellow 